\title{
Translanguaging: Claudio Giovannesi’s Postcolonial Practices
}

Derek Duncan

Department of Italian, University of St Andrews, Scotland, United Kingdom

St Andrews, Fife KY16 9PH, ded3@st-andrews.ac.uk, +(44) 1334463668

Special issue 'Postcolonial Cinemas in Europe. Migration, Identity and Spatiality in Film

Genres'

Contributor details

Derek Duncan is Professor of Italian at the University of St Andrews. He has published extensively on Modern Italian literature and film especially in relation to sexuality and Italian (post)colonial culture. His current interests are in the field of transnational Italian culture. He is co-editor of the book series 'Transnationalizing Italian Cultures' with Liverpool University Press, and co-editor of Transnational Modern Languages: A Handbook also with LUP. 


\title{
Translanguaging: Claudio Giovannesi’s Postcolonial Practices
}

\begin{abstract}
Claudio Giovannesi's Fratelli d'Italia (2009) is a documentary about the lives of three teenagers of non-Italian origins living in the Roman periphery. The third episode of the film features Nader, a second generation Italian-Egyptian and his conflicts both at school and in his family. Nader Sarhan starred in Giovannesi's later Alì ha gli occhi azzurri (2012), a feature film whose plot was loosely inspired by the life in Ostia of his younger self. Giovannesi blurs the line between documentary and fiction by casting Nader as 'himself' (members of his family also appear in both films). This blurring can be seen as one example of 'translanguaging', a way of moving across linguistic and cultural systems which suggests their permeability. Practices of translanguaging allow a movement across the familiar binary logic of the bi-national, pointing to quotidian practices of cultural difference with no clear culture of origin nor host. Nader's family's move between Arabic and Italian as they constantly re-negotiate their cultural values. Giovannesi reworks the familiar defining link between territory and language, yet the films offer no celebratory account of multilingual and multi-ethnic Europe.
\end{abstract}

Keywords: Giovannesi, translanguaging, modern tongue, Italian, Arabic.

\section{Introduction}

In an essay on cinema, subjectivity, and capital in the age of globalization, Kathleen Newman offers an urgent reminder about film's multi-layered complexity in terms of how it speaks to spectators:

How a film instantiates the geopolitical imaginary of a particular historical time and place, whom the film addresses and from what geopolitical perspective, and what a film accomplishes as a narrative are understood to be the simultaneous operation of multiple scales. (Newman 2009, 3-4)

Newman's statement echoes the point made by Shohat and Stam $(1994,205)$ that films are as much about address as representation. They are also about the processes through which the human subject comes into being: 'Given subjectivity is constituted in language, narratives are then the evidentiary sites of simultaneous multiple subject positionings' (Newman 2009, 5-6). Newman is making a broad theoretical point about language and her reflections do not distinguish between specific languages nor their contextualisation. What I want to do in this essay is take her insight into a precise geopolitical context referring to the constitution of subjects through narrative in and across specific languages. The spatial focus of my study is 
the multicultural periphery of contemporary Rome, described by Áine O'Healy as 'a space of fluid movement between Africa and northern Europe' (2009, 189). It is also a fluid linguistic space in which standard Italian and its regional variants co-exist with the multiplicity of languages spoken by Italy's new migrant population. I want to look at how film represents this heteroglossic mosaic and how it figures a subjectivity constructed not by language in the abstract, but by languages in their material location and difference. My focus is on the management of this type of mixed linguistic economy and its effects in two films directed by Claudio Giovannesi. The first Fratelli d'Italia (2009) is a documentary focussing on three teenagers of non-Italian origin living in Castelfusano, near Ostia, on the coast near Rome. The second, Alì ha gli occhi azzurri (2012), fictionalises one week in the life of Nader Sarhan, one of the boys featured in the earlier film. Nader and his parents play semi-scripted versions of themselves in a narrative which pushes to a more extreme degree some of the cultural and inter-generational conflict shown in the documentary. Both films premiered and won awards at the Rome Film Festival, and the later film, produced with financial support from the RAI and the Italian government, was widely distributed on the international film festival circuit.

A compelling feature of these films is their innovative realignment of language, space, and belonging. Indicative of this is an early scene in Fratelli d'Italia, in which Nader buys a can of spray paint. He uses it to inscribe a declaration of love to his girlfriend on a neighbourhood wall: 'Amore mio/La my vita/ 6 TT x me'. The message combines standard Italian, text speak, and, in a minimalist transnational gesture, a single word of English. Nader's message is a contribution to what has been called the 'linguistic landscape' of the urban environment, the diverse set of practices through which language is transcribed onto public space. Graffiti is only one example of these practices which include public signage, advertisements, and countless other forms of inscription. These practices demonstrate the material presence of diverse types of multilingualism, produced by a range of hegemonic and subaltern actors and voices. The interest of a 'linguistic landscape' is its proclamation of diversity, and the spatial organisation and occupation of what inevitably appears as mixed or hybrid. Graffiti may seem a particularly subaltern instance of public expression. Yet, Blackwood and Tufi interpret its widespread presence and indeed acceptance in Italian cities as 'an act of identity, rather than transgression'. The mixed linguistic structure of Nader's message is significant less for its content than for what its combination of formal properties achieves: 'If non-standard languages are represented together with Italian on a wall covered 
in graffiti, then those languages acquire legitimacy and citizenship' $(2015,11)$. What matters about this ostensibly unremarkable bit of graffiti is the way in which it asserts personal identity and cultural presence through a particular linguistic performance including, but also at odds with, the norms of standard written Italian.

The message attempts to inscribe identity in the public domain, and claim 'legitimacy and citizenship' for what might be called an 'accented' voice in the sense that its morphological features mark it as non-standard. While linguistic landscapes are normally defined by the presence of the written word, I want to extend Blackwood and Tufi's insight to the acoustic forms found in Giovannesi's two films. An important reason for this is that Nader's message contains no trace of Arabic, which he speaks at home, and which is heard extensively throughout both films. Just as Nader's graffiti asserts an identity not fully expressed by standard Italian, the multiple linguistic forms and languages heard in the films make claims on, and on behalf of, an audibly diverse nation. The formal hybridity identifiable in Nader's mural inscription underlines subjectivity as something which is unsettled, contested, and negotiated. Subjectivity, as something which is profoundly social and intimately particular, is central to Ponzanesi and Waller's definition of postcolonial cinema:

Postcolonial cinema, while maintaining engagement with collectives, refocuses on the specificity of individuals. Protagonists are not represented as ego ideals or as everypersons, though, but as multi-dimensional figures - often marginalized, subordinated, displaced, or deterritorialized - whose subjectivities as well as subject positions are open to the unexpected, the unpredictable, which may enter from somewhere beyond our particular epistemological ken. (Ponzanesi and Waller 2012, 7-8)

The representation of linguistic diversity adds further layers to the visual and narrative figuration of subjectivity characteristic of postcolonial cinema. In my discussion of Giovannesi's two films, I want to keep in mind the kind of uncertainties of place, power, and knowledge Ponzanesi and Waller point to. The places where languages are spoken becomes an essential part of the legitimacy and citizenship they voice. Both films manage a complex linguistic economy involving the co-presence of different languages, voices and accents striated by indeterminacy.

\section{Postcolonial Voices}

In the Italian context, 'postcolonial' is not a settled term, but indexes the coalescence of different historical instances of human mobility (Lombardi Diop and Romeo 2012, 1-29). 
It refers to the wide-ranging processes through which Italy has begun to remember its own colonial past and histories of emigration at the same time as it experiences the cultural and socio-economic effects of migration to the peninsula. It also signals Italy's complex investment in European colonialism more broadly, and its sometimes subaltern position as part of Europe's south (Ponzanesi 2012, 57-61). 'Postcolonial' cannot be meaningfully deployed as a 'minoritizing' category to reference only non-Italian nationals. Instead, it works as a broad and inclusive signifier of dynamic locatedness grounded in a particular geopolitical and geocritical moment. Put in the simplest terms, everyone in Italy is a postcolonial subject albeit with different modalities of belonging and power. Over the last twenty-five or so years, Italian cinema has symptomatically, if not systematically, explored Italy's domestic encounter with a postcolonial or transnational other whose fluctuating diversity has fostered an evolving yet necessarily unresolved exploration of the visual and aural economies of the nation (Duncan 2008; O’Healy 2010; Ponzanesi 2011). Elizabeth Ezra (2016) recently offered the following necessarily flexible definition of the interface and inheritances of both terms:

The transnational is actually analogous to the postcolonial: as the postcolonial bears the traces of the colonial, so the transnational bears the traces of the national. In both cases, the past haunts the present. As we become more historically distant from colonial empires, postcolonialism as an explanatory narrative becomes no less valid, but it has to make room for other narratives that can help us understand the history of social inequality on a global scale. (Ezra 2016)

The 'room for other narratives' might also be understood as a space of 'minor transnationalism' (Lionnet and Shih 2005). Lionnet and Shih open up the notion of the transnational to look for affiliations between and across individuals and collectives whose stories are not exhausted by dominant (post)colonial narratives, but which are intimately intertwined with them. The transnational intersections of Giovannesi's Roman periphery are the effects of human mobility which does not necessarily follow the routes of national colonial histories. One of the features of these stories and spaces are the 'new literacies ... created in nonstandard languages, tonalities, and rhythms' (Lionnet and Shih 2005, 8). They constitute the sound of the transnational which is the focus of what follows. ${ }^{1}$

While the visibility of migrants, or rather their conditions of visibility, have been scrutinised, particularly in relation to constructions of racial or ethnic difference (O'Healy 2009; Duncan 2011; Greene 2012; Di Franceschi 2013), ${ }^{2}$ less attention has been paid to their 
audibility - not just what the migrant voice says, but also the accent as a material signifier of irreducible alterity. Modes of audience address become particularly complex and politically charged in films where multiple languages are spoken (Berger and Komori 2012, 8). While cinema has always helped audiences deal with foreign language films through dubbing and subtitling, bilingual or multilingual films pose particular challenges (O'Sullivan 2011; Sisto 2014). Human mobility has made everyday proximity to different languages a fairly common experience making it difficult to maintain the assumption that there is a natural link between language and nation. ${ }^{3}$ Films which seek to reproduce mimetically a sense of that experience need to address aesthetic and political questions over how multiple languages are managed for spectators who will possess a varying range of linguistic competencies. What gets translated and for whom is always political. Films in which more than one language is spoken are necessarily invested in the politics of language in terms both of how this linguistic diversity is managed for the spectator, and how characters interact and speak with each other on screen. These questions are not simply of a technical nature for strategies of translation or mediation are inevitably caught up in power differentials between languages (Shohat and Stam 2006, 107). Networks of linguistic relationality are fundamental to the representational economy of film, particularly when a monolingual national space is in the process of becoming transnationally heteroglossic as in the case of contemporary Italy.

Áine O'Healy points out however that the presence of languages other than Italian in films about migration far exceeds the naively mimetic:

While many of the films foreground the humanity of the foreigner/immigrant and allow their protagonists to be heard in 'foreign' tongues of European, North African, and sub-Saharan provenance, they simultaneously reveal unresolved anxieties about the boundaries of the Italy body politic in relation to its internal and external others. (O’Healy 2010, 17)

A common trait in Italian films about migration has been the instrumentalisation of language and accent as a corporeal marker of ethnic difference. While historically, the foreign voice has often been adopted as a vehicle of comedy (Sisto 2014, 44), in films about migration it conveys a more serious inflection. In Amelio's Lamerica (1993), an aspiring Albanian migrant hopes he will marry an Italian woman and their children speak only Italian cancelling out any trace of Albanian heritage. A potential tension between visibility and audibility has been acute in films featuring East Europeans who somatically might be able to pass as Italian. The central character of De Dominicis's L'Italiano (2002) is the Albanian grandson of an 
Italian soldier, part of Italy's invading army in 1939. His claims to be Italian are undermined and made risible by the difference of his voice. Subtitling may also function as a compelling indicator of difference. Subtitles for the deaf and hard-of-hearing conventionally include not just transcriptions of what is said, but also information about audio content such as music or background sound. In Mazzacurati’s La giusta distanza (2007), the Tunisian mechanic Hassan is recorded as speaking with 'an Arabic accent' so that the deaf viewer doesn't miss the marked quality of his speech. When characters speak in languages other than Italian, almost invariably what they say is subtitled for the Italian spectator. Yet, occasionally, films play with a mixed economy of practice. In Saimir (2004), Albanian, spoken by the main characters, is systematically subtitled, while the speech of the Roma characters is not, intensifying the distancing effects for the audience. Italian may also function as a lingua franca for characters from different national or ethnic origins. While the accented voice insists on, as it performs, the alterity of non-Italians, this performance is also the first sign of a dislocation between language and territory, a key feature of a narrowly construed national film culture.

Graziella Parati has picked up on the dislocating properties of the marked voice in Italian cinema of migration as a positive assertion of cultural difference:

Film is the medium in which the accent, inscribed in the grammatical imprecisions in migrants' texts, acquires additional meaning. The sound of accented voices adds to the grammatical variants that migrants write in their novels and short stories ... Speaking with an accent means therefore thinking with an accent and expressing the difference through a sound that is an agent of change, a mark of uniqueness. (Parati 2005, 125-26)

She contrasts the effects of the accent registered through the cinematic medium with its disappearance in literature. So-called migrant writers choosing to write in their acquired language work to ensure that no traces of difference may be discerned by the reader. A mastery of Italian becomes the vehicle for effective assimilation if not citizenship. Difference is inaudible. Jennifer Burns takes this point further to argue that the fluent and accurate deployment of Italian allows the migrant a sense of empowerment or agency especially in terms of self-definition. Yet intriguingly, she notes that while Italian may be the primary mode of expression in a given text, it also functions as a frame in which non-Italian lexical items or structures can be inserted. She suggests that this type of 'interference,' drawing attention to the co-existence of two or more languages, creates a sense of 'temporary estrangement' for the (Italian) reader in a process of 'intercultural accommodation' (2013, 
188-89). Burns points out that this linguistic model tends to be an inclusive one as glossaries or notes help the reader grasp non-Italian terms. Yet she also remarks that certain words such as 'ghurba, muezzin, burqa' no longer require any effort of translation having already merged into the lexis of standard Italian. This modality of cultural fusion also signals the redefinition of the language in conceptual as well as lexical terms as Italian becomes more capacious in its discursive concerns or limits.

The notion of 'interference' is a helpful tool for understanding the representational economy of language in Giovannesi's two films, which I will suggest, propose an innovative, but not celebratory, model of linguistic, cultural, and national diversity. Rather than reinforcing national and ethnic boundaries, they intimate a new model of cultural citizenship in which cultural and national boundaries and identities are permeable and malleable. In terms of second language acquisition, interference refers conventionally to the palpable trace of the speaker's first language in the other tongue. It indexes any lexical or morphological feature which contaminates the acquired language. Yet in what I propose, interference is no longer a linguistic error, nor an indicator of an imperfect command of another tongue, but a dynamic and transformative communicative practice.

The work of García and Li Wei (2013) on 'translanguaging' revises the commonly held view that people speaking more than one language inhabit separate and autonomous linguistic and cultural systems, and suggests that interference is more about creativity than error. In the former vein, Shohat and Stam argue that: 'Possession of two languages is not a matter of having two tools. Rather, it entails participation in two conflicting psychic and cultural realms' $(2006,129)$. Bilingualism is said to generate a split subjectivity. The term 'code-switching' is commonly used to describe how people skilfully shift between separate systems moving from one language to another according to context. García and Li Wei resist the notion of the split and offer a more fluid understanding of the relationship between subjectivity and language whereby speakers move through systems in a process of continuous contamination expanding the repertoire of each language they move through. The dynamic movement of crossing - the trans - of those whose linguistic repertoire crosses languages produces 'transformative' effects on subjectivity as well as on other modes of cultural agency and practice:

as new configurations of language practices and education are generated, old understandings and structures are released, thus transforming not only subjectivities but also cognitive and social structures. In so doing, orders of discourse shift and the voices of Others come to the 
forefront, relating then translanguaging to criticality, critical pedagogy, social justice, and the linguistic human rights agenda. (García and Li Wei 2013, 3)

Crucially, García and Li Wei extend the notion of transformation beyond the realm of the linguistic to encompass also cultural, cognitive, and political change. Translanguaging goes beyond the realm of the strictly linguistic to encompass any form of semiotic activity including physical gesture and other bodily practices. In my analysis of Giovannesi's films I will argue that their management of languages develops from instances of 'code-switching' where speakers do indeed move between languages and cultures largely without interference to a more fluid situation in which the concept of translanguaging is required to describe adequately a linguistic and cultural paradigm without firm boundaries. Translanguaging as creative practice has profound implications for postcolonial cultures and subjects.

\section{Giovannesi’s Linguistic Economies}

Fratelli d'Italia is set in a secondary school on the Lazio coast in which $40 \%$ of the student body is of non-Italian origin. The film is divided into three episodes, each focussing on the life of a different pupil with quite contrasting experiences and family situations. The film clearly implies that there is no single model of identity for 'second generation' Italians. ${ }^{4}$ The first section features Alin Delbaci, a Romanian boy living with his family on the Roman periphery, the stark desolation of which is conveyed through a number of sequences of Alin driving his motorbike through anonymous housing estates and past empty beaches. These sequences are regularly intercut with scenes shot in the school with teachers and classmates discussing him in his absence. School is a site of conflict where Alin is seen a negative, disruptive presence. The model of intercultural contact in this section of the film upholds clear boundaries between Italian and non-Italian. Alin speaks fluently in Italian, but his conversations with his family and friends outside school are invariably in Romanian and subtitled for the Italian audience. In a scene in a Chinese restaurant, which bears useful comparison to two scenes I will discuss later, Italian is used to converse with the Chinese waiter, and while all members of the family appear comfortable speaking in Italian, they revert to Romanian when speaking to each other. This rigid bilingualism is maintained in the film's second section which focuses on Masha Carbonetti, a girl from Belarus adopted by an Italian family. In touch with her brother after several years' separation, she speaks to him regularly by phone, making firm, but ill-defined plans to visit him. Their conversations are subtitled, underlining his geographical and cultural distance. Despite the support of her adoptive family and Italian boyfriend, Masha does not visit, and the spectator learns at the 
end of the film that she spends three months in the US instead. These transnational narratives call into questions commonplaces of the migrant experience, not least around issues of belonging and locatedness. As an EU citizen, Alin and his family are perfectly at home in Italy, and it is clear that Masha, now an Italian through her adoption, has little inclination to return to Belarus and her childhood of neglect and abuse. Their organisation of language is nevertheless identical to that in Vincenzo Marra's Tornando a casa (2001). Set in Naples, the film's soundtrack features both Neapolitan and Arabic, yet as Camille Gendrault has noted they 'never interfere [my emphasis] with one another. Heard in alternation throughout the soundtrack and always kept distinct, they correspond to one or other of the two worlds in which Samir [the main Tunisian character] evolves' (2012, 234). In Tornando a casa, and in the first two sections of Fratelli d'Italia, the linguistic model proposed is one in which codeswitching is a question of technical competence allowing people to move between incompatible and separate linguistic and cultural systems.

A more complex transnational narrative emerges in the third part of the film featuring Nader Sarhan, whose Egyptian parents became Italian citizens before he was born. The film charts the tensions in his life at school and at home detailing conflicts between and across religion, generation, gender, and cultural expectation. School is again a site of conflict, but for Nader it is also the place where strong bonds of friendship have been made. He socialises with other Italians both in and out of school, and unlike Alin, has an Italian girlfriend and is on very good terms with her parents. Nader's identity as an Egyptian Italian is a central thread of the film. While he does identify as Muslim, he challenges religious practice when it comes into conflict with the norms of his friends. Nader speaks with a strong Roman accent, yet also speaks Egyptian Arabic, inserting short phrases into conversations with his Italian friends. His family speak primarily in Arabic at home, but as I will go on to discuss, is comfortable speaking Italian and often switches between the two languages, sometimes midsentence. The predicable practice of bilingual code-switching heard in the first two sections of the film where firm boundaries are maintained between language, place, and identity gives way to a more porous or fluid system of linguistic practice. In Nader's story, 'interference' emerges as both a fact of intercultural life and a modality of cultural fusion and exchange. Nader's voice is the vehicle for its unaccented transmission. The ductility of his vocal performance puts pressure on the Italian language as the site of audible difference. His accent does not mark him out, yet it would be wholly wrong, as well as incorrect, to say that it functions as a disguise; this would assume in advance Nader's irreducible alterity. Here, the 
riff of his accent is conversely its very locatability in Rome. Yet, while Nader's family, even at moments of high tension, moves freely between Arabic and Italian, this fluidity is not acceptable elsewhere. At one point, Nader receives a short expulsion from school for disruptive behaviour. One of the reasons given by his teachers is that he speaks Arabic in school. This stark division of linguistic possibility which initially seems to indicate a familiar pattern of binary identification and exclusion, contrasting state institutions with places of affective belonging, is one which both films investigate yet reveal a more complex set of exclusionary mechanisms. Attention to how Nader is placed and moves in and across linguistic and cultural systems tracks these processes.

Language and voice are of course aspects of corporeal performance. The body is a prime resource for the management of cultural difference both by virtue of its capacity for transformation, but also through its recalcitrant materiality. Giovannesi constructs Nader within a recognisably Italian economy of representation which historicises his subjectivity. Alì ha gli occhi azzurri's title is a slight reworking of a collection of writings by Pier Paolo Pasolini written between 1950-65. Ali dagli occhi azzurri sketches the contours of his erotically and driven politically radical Rome inhabited by boys from the 'borgate', the Roman periphery, in whom Pasolini saw the traces of a pre-modern Italian culture offering a redemptory presage for the future. Many were migrants, or the sons of migrants, from the South. They were characterised by their speech, the dialect through which they voiced a dissonance from the developing homogenizing national culture that Pasolini abhorred. Yet the figure of Alì himself comes from the poem 'Profezia':

Alì dagli Occhi Azzurri/uno dei tanti figli di figli/scenderà da Algeri/su navi a vela e a remi./Saranno con lui migliaia di uomini/coi corpicini e gli occhi/di poveri cani dei padri (Pasolini 1992, 488)

The poem has been seen as a prescient anticipation of postcolonial mobility (Bouchard 2010, 104). Prophetic or not, Pasolini's political and erotic figuration both of the 'borgate' and then later of Africa has provided film-makers with a compelling cinematic lexis through which to claim a redemptive political legacy (Restivo 2002, 149, 155). Indeed films about migration have drawn liberally on Pasolini's legacy as a means of narrating, but also visualizing the young male migrant body. Like Pasolini's ragazzi, they are often involved in petty crime with a value system at odds with the state and its institutions. Shot on location, Pasolini's Roman films and those of his postcolonial descendants, tend to be set in an anonymous periphery, avoiding the clichés of the monumental eternal city (Steimatsky 2008, 119). ${ }^{5}$ 
Alì ha gli occhi azzurri contains a number of these aesthetic and narrative features, ensuring that Nader, in terms of the economies of his representation, is situated within a securely Italian iconographic tradition. The film's plot is relatively simple unfolding across a single week. It opens with Nader and his friend Stefano carrying out a robbery. Sharing the same language and accent, the boys are Pasolinian subjects in equal measure. Back at school, Nader controversially removes the crucifix from the classroom wall. Islam also creates conflict at home where he argues with his parents, particularly his mother, about his Italian girlfriend. He defies the curfew placed on him and as a result is locked out of his home. This curfew had in fact been threatened in Fratelli d'Italia so the later film constitutes a fictional alternative future for Nader and his family. ${ }^{6}$

Alì ha gli occhi azzurri displays a greater degree of linguistic self-consciousness than the earlier film. The days of the week are inscribed on screen in Italian and in Arabic, appearing on the left and right of the frame respectively to mark time passing and contributing graphically to the film's linguistic landscape (Shohat and Stam 2006, 107). Yet their appearance also reminds the audience of the dual yet shifting cultural frame of the narrative. Both films contain a scene in which a family meal provides the staging for conflict, foregrounding the negotiation of different cultural codes across both languages. In Fratelli d'Italia, the scene opens with the mother bringing food to table greeting her family in Arabic. The subsequent conversation moves seamlessly between Italian and Arabic as the family chat about football and row over Nader's Italian girlfriend. The scene is reprised in Alì ha gli occhi azzurri where it is the first sequence of 'Sunday'. As in the earlier film, the family moves between languages, and the cultural values associated with both are discussed in both Arabic and Italian. Both languages are used by all members of the family albeit with some variation in range and accent. The tenor of the linguistic exchange is instructive. The family's 'linguistic repertoire' (García and Li Wei 2013, 2) allows them to range freely over conventional cultural boundaries. The family is a 'translanguaging space' (García and Li Wei $2013,24)$ in which the cultural dichotomies seen in the stories of Alin and Masha in Fratelli d'Italia are broken down. García and Li Wei optimistically align this space with that of Edward Soja's 'Thirdspace' with its potential for cultural transformation (2013, 25). I argue that Alì ha gli occhi azzurri presents a more dystopian version of that radical vision. ${ }^{7}$

\section{Dissonant Voices}


In Fratelli d'Italia discussion of cultural difference is initially good-humoured, but the scene ends on a note of irreconcilable difference with a close-up of a defiant Nader which cuts to a close-up of his clearly irritated mother. In both films, the primary axis of cultural tension in the family is between mother and son whose arguments are conducted almost equally in Italian and Arabic. Contrasting gender roles and spaces are delineated across multiple axes of difference. Nader's mother's attachment to domestic and religious traditions pits her against Nader's more secular, Italian identity. He distances himself from the perspectives of his Muslim Egyptian family, where religious and national identities clearly intersect. His cousin conflates the two: '[sex before marriage] is forbidden. [You] are Egyptian. Islam doesn't allow such things'. The family's linguistic virtuosity renders the conventional sense of the term 'mother tongue' unworkable. Within the hegemonic linguistic discourse of Italian postcolonial cinema, Nader's 'mother tongue' is Egyptian Arabic although his preferred mode of expression is probably Italian inflected with his Roman accent. The term 'mother tongue' is often used as a means of welding the speaker to a particular language which functions as the symbolic bottom line or bedrock of cultural identity. With this in mind, Yasemin Yildiz has argued that this overly familiar metaphor has powerful effects far beyond its efficacy in describing a person's relationship with language. She notes: 'the 'mother' - a markedly gendered kinship concept - stresses a static mode of belonging to the national collective .... The uniqueness and organic nature of language imagined as 'mother tongue' lends its authority to an aesthetics of originality and authenticity' $(2012,9)$. Yildiz additionally questions the assumption that the 'mother tongue' is inevitability the language through which the human subject will experience emotion while other languages represent alienating and distancing barriers to self-expression. Alì ha gli occhi azzurri consistently unsettles appeals to a hegemonic aesthetics of belonging in which the migrant could be seen solely in terms of a bounded and gendered culture of affect and origin. The ability of Nader and his family to move emotionally and expressively across languages points to an affective landscape not constrained by national and linguistic boundaries. Yet this is not a celebratory achievement. On Friday, he visits the mosque and watches his mother and sister through the partition separating the areas allocated to men and women for prayer. The habitation of this stark articulation of gendered and culturally specific space is at stake in both films. The close-up of his mother weeping in the mosque is paralleled with the film's final shot of Nader standing in tears outside his girlfriend's apartment block. He had becomes estranged from the families of Stefano and Brigitte, his girlfriend, as well as his own. The scene then cuts to his family's living room where they are 
sitting at dinner. It is shot from the deep space behind where Nader would have sat. The dinner is punctuated by the standard Arabic of the TV journalist commenting on the events of 2011. The family is not looking at the television, but towards the empty space left by Nader. The film's conclusion is not about the happy integration of different cultural systems, but of the failure of cultural translation.

Yildiz puts pressure on the belief that monolingualism represents the natural, or at least most frequently experienced, human condition. Yet bi- or plurilingual spaces can be difficult to negotiate and inhabit. García and Li Wei draw on Derrida's concept of 'brisure', translated in English as 'joint' or 'hinge', to reference 'practices where difference and sameness occur in an apparently impossible simultaneity’ (García and Li Wei 2013, 21). To recognise the possibilities of the translanguaging subject is not to fall back into the more celebratory excesses of an easy multiculturalism. J. Hillis Miller talks about 'brisure' in terms of the 'disarticulated articulations', the breaks between words where meaning is produced $(2011,43)$. Nader is stuck, I would suggest, in this transformative in-between space of the 'brisure'.

His tears and the outside space in which he weeps are an instance of corporeal dissonance underlining the fact that the body is out of joint. If his voice allows him to pass as Roman, there is less confidence that his body will. In her discussion of the 'transnational' as analytical tool, Emma Bond identifies the positionality of the body as a form of 'brisure' or 'hinge':

Indeed, the body, as privileged site of lived subjectivity, yet also as a means of experiencing the local and the global simultaneously, becomes an important hinge of meaning within a mapping of the trans-national. (Bond 2014, 416)

For Nader, the embodied habitation of the transnational 'hinge' becomes untenable and unutterable. In Fratelli d'Italia, Nader's story had begun with a close-up of him inserting blue contact lenses into his naturally dark eyes, a habit which is repeatedly highlighted in both films. The later feature film deliberately blurs the boundary between fact and fiction making the blue contact lenses part of the semiotic repertoire of the translanguaging subject. The film's title from the outset draws attention to the significance the artifice of the blue eyes. The contact lenses transform his body, repeatedly, but never permanently. Close-ups afford a heightened significance to the gesture, yet how to interpret what Nader does remains a problem. For Brigitte, his persistence in using the lenses is laughable. But is it simply the 
expression of personal preference, a minor act of vanity, or does it pose more difficult questions about the naturalness, authenticity, or locatedness of Nader's bodily presence? In an interview, Sarhan states that he used the lenses to make himself 'look like someone else,' and points out that in Alì ha gli occhi azzurri, the character he plays tries to imitate Stefano. Disguise and imitation recur throughout the film. Nader and Stefano wear carnival masks in their comically ill-fated attempt to rob a prostitute. This fusion of the corporeal identities of Stefano and Nader is most vividly acted out when they shave together sharing a mirror with Stefano's father who encourages Nader to go home. His disavowal of his family is absolute dismissing them as 'totally Arab,' yet the disavowal itself does not secure his ambition to 'pass' as a corporeally 'unaccented' Italian.

In this bathroom scene, a remark by Stefano about Laura, Nader's sister, hints at the inevitable rupture of their bond and the difficult intersectionality of ethnicity and masculinity. Later, Nader's eye lingers on a photo of a younger Stefano's confirmation ceremony, shot in close-up. Diegetically, the brief shot seems unmotivated, yet it creates a critical hiatus, a space of cultural and historical interference, in the boys' friendship. Nader may be a resistant Muslim, yet the photo is an unspoken, albeit expressive reminder of his difference from Stefano: there will never be a picture of Nader's confirmation. The entanglement of religious and gender difference undoes Nader. When he comes across Laura kissing Stefano in his car, he smashes the windscreen with his gun and pulls her into the street. Although he fires several shots at the fleeing Stefano, the key element of this scene is that he addresses his sister in Arabic rather than Italian, until then the primary vehicle of communication between them. This sudden reversal shifts the translanguaging Nader to another space, and arguably to the cultural and gender values of his 'mother tongue', while Laura stands in Nader's former place as a gendered Italian subject. He does not return home, however, and the film's ending shows him still locked out with no place to go.

Nader's postcoloniality depends on, and is expressed through, the vicissitudes of corporeality, and its entanglement in language. The voice of Nader's narrative is one of Newman's 'evidentiary sites of simultaneous multiple subject positionings' $(2009,4)$. His postmonolingual subjectivity nonetheless compromises, as it simultaneously facilitates, his capacity for trans-cultural crossing. Giovannesi's work represents spaces where transnational subjects translanguage to 'employ, create, and interpret different kinds of linguistic signs to communicate across contexts and participants and perform their different subjectivities' (García and Li Wei 2013, 28). Their linguistic repertoires sever the defining link between 
territory and language fundamental to European constructions of identity. Yet Nader as a new Italian, or new European, is not always successful in mediating across contrasting cultural systems. His acts of trespass expand the semantic repertoire of both Italian and Arabic through practices of cultural interference. This interference hinges on, and is unhinged, by Nader's (non)accented voice which doesn't belong to a single place, and is constantly in motion. His blue eyes resonate with his provisionality. His 'mother tongue' is not a space of stability or return. Both Giovannesi's films are about subjectivity, an interiority emphasised by the use of often extreme close-ups of faces and body parts, and an exteriority communicated through wide angle tracking shots of the Roman periphery. For Nader, the cultural fusion of the translanguaging experience is one of homelessness, the 'brisure' of irreconcilable and inexpressible difference. Symbolically, the closing credits of Fratelli d'Italia tell the spectator that while Alin passed his end of year school exams, Nader didn't. In both films, Nader changes school in the hope of finding a more settled space. His ongoing displacements are 'evidentiary sites' of Europe's ongoing attachment to and investment in proper belongings of language and space. Nevertheless, Nader still (dis)articulates the changing voice of the nation, and initiates a new modality of audience address in transnational cinema.

Notes

\footnotetext{
${ }^{1}$ Italian films which specifically foreground the postcolonial condition, like much Italian cinema, are primarily a local enterprise (Zagarrio 2015, 325-28). In terms of production, distribution, and exhibition, they generally register little presence outside the nevertheless important international festival circuit. Yet films dealing explicitly with Italy's postcolonial experience are essential for apprehending the nation's conflicted response to global mobility, demographic change, and cultural memory. The earliest Italian films about migration tended to focus on the catastrophe of migration with an emphasis on homelessness and return as the inevitable, tragic consequences of failed assimilation. Gradually however, films of social critique have been replaced by genre products - comedies, romantic-comedies, thrillers - in which the migrant has become a resident if not always citizen, and what remains to be explored are the actual terms of that permanence. Most of these films have been directed by white Italians who have been able to draw on funding opportunities offered by government bodies or privately-owned television companies, as well as on established channels for European co-production. Few have been directed by non-Italians or recent migrants to Italy (Bonsaver 2015, 346-57).

${ }^{2}$ The focus of my discussion will be on how so-called migrants speak in Italian postcolonial cinema. I am specifically not referring to films which might be encompassed under Naficy's (2001) rubric of 'Accented Cinema.' His hugely influential work relates primarily to the accent of film-makers themselves and its translation into the aesthetic structures of their
} 
work. I am interested here in the management of voice (including accent) in films which in his terms are 'unaccented.'

${ }^{3}$ Films which feature more than one language test the limits of national cinema which is often characterised by a rigid monolingualism. The exclusion of Saverio Costanzo's Private (2004) from the Oscars because Arabic and Hebrew are the languages spoken in what purported to be an Italian film demonstrates the degree to which national cinema has been determined by language and its conflation with territory. This restriction was subsequently lifted.

4 'Second generation' is a widely used albeit very ill-defined category in Italy. As well as serving to create a fissure in Italian identity, it has also been used by groups such as 'Rete 2 Seconde Generazioni' as a channel for social activism. The group now conducts most of its activities through Facebook: https://www.facebook.com/groups/41820491538.

${ }^{5}$ As well as Saimir, films such as Botrugno and Coluccini's In terra pax (2010), and Noce's Good Morning Aman (2009) situate themselves self-consciously in this tradition of representation. Rhodes notes that the location of Accattone (1961) was in the mid-2000s, being used as a temporary migrant settlement $(2007,50)$, drawing attention to the palimpsestic layering of connectedness, and the intersections of filmic and pro-filmic versions of the city. In addition, all the films mentioned contain a homoeotic/queer stratum which I do not have the space to explore here, but which underlines and is underlined by the recourse to Pasolini's aesthetic repertoire.

${ }^{6}$ Nader also features in an episode of Permesso di soggiorno, a series of short films about young people of non-Italian origins living in Italy made by Avoicomunicare, a Youtube channel set up by Telecom Italia. Nader talks about himself and his family in ways which echo the two films, but carry more nuance. It adds a further intertext to Nader as a postcolonial subject: https://www.youtube.com/watch? $\mathrm{v}=\mathrm{d} 4 \mathrm{mCMzgCSt} 0$. It should be pointed out that as an Italian citizen, Nader does not need a residence permit, the 'permesso di soggiorno' of the series' title.

${ }^{7}$ While the subtitling of Arabic dialogue into Italian underlines the power differential between the languages in the context of the film's production and distribution, it does not disguise the fact that the conversation is a remarkable instance of the linguistic displacement of the nation as Arabic becomes an Italian language.

\section{References}

Amelio, Gianni, dir. 1994. Lamerica. Italy: Alia Film.

Berger, Verena, and Miya Komori, eds. 2012. Polyglot cinema: Migration and Transcultural Narration in France, Italy, Portugal and Spain. Münster: LIT Verlag.

Blackwood, Robert J. and Stefania Tufi. 2015. The Linguistic Landscape of the

Mediterranean: French and Italian Coastal Cities. Basingstoke: Palgrave Macmillan. 
Bond, Emma. 2014. “Towards a trans-national turn in Italian Studies?.” In: Italian Studies (Cultural Studies issue) 69 (3): 415-24.

Bouchard, Norma. 2010. "Reading the Discourse of Multicultural Italy: Promises and Challenges of Transnational Italy in an Era of Global Migration.” In: Italian Culture 28 (2): 104-20.

Bonsaver, Guido. 2015. “Accented Voices in Contemporary Italian Cinema.” In Destination Italy: Representing Migration in Contemporary Media and Narrative, edited by Emma Bond, Guido Bonsaver, and Federico Faloppa, 345-64. Oxford: Peter Lang.

Botrugno, Matteo and Daniele Coluccini, dir. 2010. Et in terra pax. Italy: Kimerafilm. Burns, Jennifer. 2013. Migrant Imaginaries: Figures in Italian Migration Literature. Oxford: Peter Lang.

Costanzo, Saverio, dir. 2004. Private. Italy: Istituto Luce.

De Dominicis, Ennio, dir. 2002. L'Italiano. Italy: Poetiche cinematografiche.

Di Franceschi, Leonardo, ed. 2013. L'Africa in Italia. Per una controstoria postcoloniale del cinema italiano. Rome: Aracne.

Duncan, Derek. 2008. "Italian postcolonial cinema and its histories of representation." In: Italian Studies 63 (2): 195-211.

Duncan, Derek. 2011. "Double time: Facing the future in migration's past.” In: California Italian Studies 2 (1): http://escholarship.org/uc/item/38q389mk

Ezra, Elizabeth. 2016. "Transnational Cinemas. A Critical Roundtable", edited by Austin Fisher and Iain Robert Smith. In: Frames Cinema Journal. http://framescinemajournal.com/article/transnational-cinemas-a-critical-roundtable/

García Ofelia and Li Wei. 2013. Translanguaging: Language, Education and Bilingualism. Basingstoke: Palgrave Macmillan.

Gendrault, Camille. 2012. "Dialect and the Global: A Combination Game." In Polyglot cinema: Migration and Transcultural Narration in France, Italy, Portugal and Spain, edited by Verena Berger and Miya Komori, 229-40. Münster: LIT Verlag.

Giovannesi, Claudio, dir. 2009. Fratelli d'Italia. Italy: Il Labirinto. 
Giovannesi, Claudio, dir. 2012. Ali ha gli occhi azzurri. Italy: Acaba Produzioni.

Greene, Shelleen. 2012. Equivocal Subjects: Between Italy and Africa-Constructions of Racial and National Identity in the Italian Cinema. New York: Continuum.

Hillis Miller, J. 2011, “Brisure.” In Reading Derrida's Of Grammatology, edited by Sean Gaston and Ian Maclachlan, 41-43. New York: Continuum.

Lionnet, Françoise, and Shu-mei Shih, eds. 2005. Minor Transnationalism. Durham and London: Duke University Press.

Lombardi-Diop, Cristina, and Caterina Romeo, eds. 2012. Postcolonial Italy: Challenging National Homogeneity. New York: Palgrave Macmillan.

Mazzarcurati, Carlo, dir. 2007. La giusta distanza. Italy: Fandango.

Marra, Vincenzo, dir. 2001. Tornando a casa. Italy: Classic.

Munzi, Francesco, dir. 20014. Saimir. Italy: Orisa Produzioni.

Naficy, Hamid. 2001. An Accented Cinema: Exilic and Diasporic Filmmaking. Princeton: Princeton University Press.

Newman, Kathleen. 2009. "Notes on Transnational Film Theory - Decentred Subjectivity, Decentred Capitalism.” In World Cinemas, Transnational Perspectives, edited by Nataša Durovičová and Kathleen Newman, 3-11. London: Routledge.

Noce, Claudio, dir. 2009. Good Morning, Aman. Italy: DNA Cinematografica.

O’Healy, Áine. 2009. “"Non è una somala:” Deconstructing African Femininity in Italian Film.” In: The Italianist 29 (2): 175-98.

O’Healy, Áine. 2010. “Mediterranean Passages: Abjection and Belonging in Contemporary Italian Cinema.” In: California Italian Studies 1(1): http://escholarship.org/uc/item/2qh5d59c.

O’Sullivan, Carol. 2011. Translating Popular Film. Basingstoke: Palgrave Macmillan.

Parati, Graziella. 2005. Migration Italy: The Art of Talking Back in a Destination Culture.

Toronto: Toronto University Press.

Pasolini, Pier Paolo, dir. 1961. Accattone. Italy: Arco Film.

Pasolini, Pier Paolo. 1992. "Profezia.” In: Alì dagli occhi azzurri. 488-93. Milan: Garzanti 
Permesso di soggiorno, 2012. https://www.youtube.com/watch?v=d4mCMzgCSt0.

Ponzanesi, Sandra. 2011. "Europe in Motion: Migrant Cinema and the Politics of Encounter." In: Social Identities 17 (1): 73-92.

Ponzanesi, Sandra. 2012. "The Postcolonial Turn in Italian Studies: European Perspectives." In: Postcolonial Italy, edited by Cristina Lombardi-Diop and Caterina Romeo, 51-70. New York Palgrave Macmillan.

Ponzanesi, Sandra and Marguerite Waller, eds. 2012. Postcolonial Cinema Studies. London: Routledge.

Restivo, Angelo. 2002. The Cinema of Economic Miracles: Visuality and Modernization in the Italian Art Film. Durham: Duke University Press.

Rhodes, John David. 2007. Stupendous, Miserable City: Pasolini's Rome. Minneapolis and London: Minnesota University Press.

Shohat, Ella and Robert Stam. 1994. Unthinking Eurocentrism: Multiculturalism and the Media. New York and London: Routledge.

Shohat, Ella and Robert Stam. 2006. "The cinema after Babel: language difference and power.” In: Taboo Memories, Diasporic Voices. Ella Shohat. 106-38. Durham and London: Duke University Press.

Sisto, Antonella. 2014. Film Sound in Italy. New York: Palgrave Macmillan.

Steimatsky, Noa. 2008. Italian Locations: Reinhabiting the Past in Postwar Cinema. Minneapolis: University of Minnesota Press.

Yildiz, Yasemin. 2012. Beyond the Mother Tongue: The Postmonolingual Condition. New York: Fordham University Press.

Zagarrio, Vito. 2015. "Imagined Journeys: Italian Directors and Immigration." In: Destination Italy: Representing Migration in Contemporary Media and Narrative, edited by Emma Bond, Guido Bonsaver, and Federico Faloppa, 325-44. Oxford: Peter Lang. 